\title{
PERAN GURU DALAM UPAYA MENINGKATKAN KUALITAS BACA TULIS AL-QUR'AN DI TPQ MIFTAHUL ULUM NGLELE SUMOBITO JOMBANG
}

\author{
Ali Muhsin \\ alimuhsin@ fai.unipdu.ac.id \\ Universitas Pesantren Tinggi Darul ‘Ulum (UNIPDU) Jombang
}

\begin{abstract}
The effort to improve Al-Qur'an reading and writing becomes the main factor is the improvement of the quality of human resources that is teacher. Teachers have characteristics as mentors who are able to show the dynamic interaction between teachers and learners. The purpose of the study to know how the role of teachers in an effort to improve the quality of literature AlQur`an in TPQ Miftahul Ulum Nglele Sumobito Jombang. This type of descriptive qualitative research with interview method, observation and documentation. Analytical techniques using data reduction (data reduction), data display (data presentation), data conclusing drawing / verification. In reading the Qur'an the learner is not a thing that goes without a process, but requires a concrete teacher's efforts. The result of the teacher's role in the effort to improve the literacy of the Qur'an is very satisfactory as evidenced by the santri can read Al-Qur an well and correctly.
\end{abstract}

Keywords: Role, teacher, effort, read Al-Qur'an

\section{PENDAHULUAN}

Sejak manusia lahir kedunia, telah dibekali oleh Allah swt dengan adanya rasa ingin tahu. Adapun wujud dari keingintahuan ini adalah adanya akal. Dengan akal manusia berpikir sehingga dia mendapatkan ilmu pengetahuan yang semakin lama akan terus berkembang. Untuk memanifestasikan kemampuan akal itu, maka diperlukan pendidikan. Pendidikan merupakan hal terpenting dalam kehidupan kita, sebagaimana Allah swt memerintahkan Nabi Muhammad saw dengan perintah Iqra' (bacalah) yang tertera dalam surat Al-'Alaq ayat 1-5.

Artinya: Bacalah dengan (menyebut) nama Tuhanmu yang Menciptakan.Dia telah Menciptakan manusia dari segumpal darah. Bacalah dan Tuhanmulah Yang Maha Pemurah. Yang mengajar (manusia) dengan perantaraan Kalam. Dia mengajar kepada manusia apa yang tidak diketahuinya. 
Ayat tersebut merupakan perkenalan dan petunjuk dari Allah swt. Bahwa Dialah pencipta segala sesuatu di jagat raya ini dan telah menciptakan manusia dari segumpal darah melalui proses yang telah ditetapkan oleh Allah swt. Allah swt menyatakan diri-Nya bahwa Dialah yang Maha pemurah, sehingga bukan untuk dijauhi apalagi ditakuti. Akan tetapi harus didekati sendiri. Dialah Maha pendidik yang bijaksana, mendidik manusia dengan ilmu pengetahuan dan dengan menulis dan membaca.

Dari makna ayat ini dapat kita ambil kesimpulan bahwa, sebagai makhluk yang mampu menerima pendidikan atau makhluk yang bisa dididik, menuntut ilmu sangatlah penting bagi kelangsungan hidup kita didunia. Dalam proses pendidikan upaya atau usaha guru sangatlah penting demi kelangsungan proses belajar mengajar yang baik. Dalam pengertian upaya atau usaha mempunyai arti yang sama yaitu ikhtisar untuk mencapai sesuatu yang hendak dicapai.

Sedangkan pengertian guru itu sendiri adalah pendidik professional, karena secara implisit ia telah merelakan dirinya menerima dan memikul sebagian tanggung jawab pendidikan yang sebenarnya menjadi tanggung jawab pendidikan yang sebenarnya menjadi tanggung jawab para orangtua. Keberhasilan suatu pendidikan banyak ditentukan oleh adanya hubungan kasih sayang antara guru dan anak didik. Hubungan ini membuat anak didik merasa tenteram sehingga tidak merasa takut pada gurunya atau lari dari ilmunya.Guru adalah publik figur yang akan dijadikan panutan para anak didiknya. Oleh sebab itu, perilaku guru baik bersifat personal maupun sosial, senantiasa dijadikan parameter sebagai sosok guru. Maka sebagai seorang guru harus memiliki akhlak yang luhur yang nantinya bisa dijadikan suri teladan bagi anak didiknya.

Dalam usaha peningkatan kemampuan baca tulis Al-Qur'an pada anak didik juga tidak terlepas dari upaya guru. Terlebih anak didik yang dimaksud adalah anak-anak sekolah dasar, yang notabene masih banyak sekali yang belum mampu dan memerlukan bimbingan yang ekstra dari guru agama untuk meningkatkan kemampuan baca tulis Al-Qur'an mereka. Karena kemampuan membaca dan menulis termasuk ketrampilan yang harus dipelajari dengan sengaja. Tidak sama halnya dengan belajar berbicara. Kemampuan mendengarkan dan berbicara termasuk kemampuan yang diperoleh dengan sewajarnya; maksudnya anak mempelajari fungsi itu dengan sendirinya. Sebagaimana dalam GBPP mata pelajaran PAI kurikulum 1994 yang kemudian disempurnakan kembali pada kurikulum tahun 1999, 
dengan penjabaran indikator-indikator keberhasilan yang diharapkan dari lulusan pada jenjang Sekolah Dasar sebagaimana uraian berikut :

Pada jenjang Pendidikan Dasar, kemampuan-kemampuan dasar yang diharapkan dari lulusannya adalah dengan landasan iman yang benar. Siswa mampu membaca, menulis, dan memahami ayat-ayat pilihan, dengan indikator-indikator :

siswa mampu membaca ayat-ayat pilihan

siswa mampu menulis ayat-ayat pilihan

siswa mampu memahami terjemahan ayat-ayat pilihan. Pada Indikator-indikator di atas dapat dilihat bahwa memang kemampuankemampuan yang diharapkan pada jenjang Sekolah Dasar adalah salah satu diantaranya anak didik mampu dalam membaca dan menulis ayat Al-Qur'an.

Baca tulis Al-Qur'an di sekolah Dasar adalah berada di dalam bidang studi Pendidikan Agama Islam (PAI). Yang mana kita telah mengetahui bahwa jam pelajaran bidang studi PAI di sekolah umum lebih sedikit porsinya jika dibandingkan dengan sekolah yang berlabel agama. Maka, tidak heran jika kita mendengar apabila ada anak SD yang masih kurang mampu dalam hal baca tulis Al-Qur'an, tetapi jangan sampai menjadi alasan dengan tidak adanya usaha atau upaya konkrit dari seorang pendidik khususnya.

Pembelajaran Al-Qur'an sebenarnya tidak hanya menjadi tugas guru di sekolah, tetapi menjadi tugas kita sebagai orang mukmin. Orang mukmin yang percaya dengan kitabullah yaitu Al-Qur'an yang menjadi pedoman kita semua. Agar para siswa khususnya disini yaitu siswa Sekolah Dasar dapat memahami isi Al-Qur'an, maka salah satu caranya adalah dengan mampu membacanya. Dalam agama Islam melaksanakan pendidikan dan pengajaran Al-Qur'an adalah amalan ibadah kita kepada Allah SWT. Orang tua yang mengajar anak baca tulis Al-Qur'an merupakan bentuk pemenuhan hak terhadap anak, yaitu hak untuk memelihara anak agar terhindar dari api neraka.

Pendidikan merupakan kebutuhan mutlak bagi kehidupan manusia yang harus dipenuhi sepanjang hayat. Pendidikan dapat diartikan sebagai proses dengan menggunakan metode tertentu sehingga seseorang akan mendapatkan pengetahuan, pemahaman dan cara bertingkah laku yang sesuai dengan kebutuhan manusia. ${ }^{1}$

\footnotetext{
${ }^{1}$ Muhibbin Syah, Psikologi Pendidikan dengan Pendekatan Baru (Bandung: Rosdakarya, 2005), 10 .
} 
Globalisasi yang melanda berbagai dimensi kehidupan, sedikit menimbulkan dampak terhadap berbagai bidang secara umum. Pengaruh tersebut ada yang positif, namun ada pula yang negatif. Dampak positifnya adalah semakin majunya teknologi informasi maka semakin maju pula perkembangan pendidikan, khususnya terkait dengan mutu dan kualitas. Perkembangan teknologi juga membawa dampak negatif bagi santri dan santriwati untuk belajar Al-Qur'an. Santri lebih suka menghabiskan waktu berjam-jam di depan komputer untuk main game dibanding dengan mengeja huruf Al-Qur'an. Hal ini berkaitan dengan teori menurut Adi Suryanto yang menyebutkan bahwa lingkungan keluarga merupakan tempat dimana santri berinteraksi sosial dengan orang tuanya yang paling lama sehingga upaya dalam meningkatkan prestasi belajar di fokuskan kepada keluarga kemudian sekolah. $^{2}$

Tugas utama dari keluarga bagi pendidikan anak ialah sebagai peletak dasar bagi pendidikan akhlak dan pandangan hidup keagamaan. Sifat dan tabiat anak sebagian besar diambil dari kedua orang tuanya dan dari anggota keluarga yang lain. ${ }^{3}$

Berkaitan dengan masalah ini peran guru untuk meningkatkan kualitas baca tulis Al-Qur`an diharapkan besar pengaruhnya untuk keberhasilan proses belajar menulis dan membaca Al-Qur'an di TPQ Miftahul Ulum Nglele Sumobito Jombang. Program menulis dan membaca Al-Qur'an ini wajib di ikuti semua santri dan santriwati di TPQ Miftahul Ulum Nglele Sumobito Jombang. Karena di TPQ tersebut merupakan suatu lembaga pendidikan yang berwawasan Islam, yang mana semua santri dan santriwati yang sudah hatam diharapkan dapat membaca dan menulis dengan benar. Akan tetapi, hal ini agak sulit dikerjakan karena untuk baca tulis AlQur'an sangat dibutuhkan semangat dan dorongan yang kuat dari santri dan santriwati. Waktu untuk menulis ayat-ayat Al-Qur`an di laksanakan pada hari senin dan jum`at jam 2 siang sampai jam 4 sore. Kalau membaca Al-Qur`an dilaksanakan pada hari selasa, rabu, sabtu dan minggu jam 2 siang sampai jam 4 sore. Satu TPQ ada dua guru dan mereka dibagi menjadi dua kelompok dalam membaca Al-Qur`an. Dalam pengelompokannya juga ada pertimbangan dalam membentuk kelompok sesuai perkembangananak.

\footnotetext{
${ }^{2}$ Adi Suryanto., dkk. Evaluasi Pembelajaran di SD (Jakarta: Universitas Terbuka, 2008), 1. ${ }^{3}$ Amir Daien Indrakusuman, Pengantar Ilmu Pendidikan (Surabaya: Usaha Nasional, 1973), 109.
} 
Sesuai tahap perkembangan siswa perlu adanya upaya untuk mendorong kemajuan santri, salah satu upayanya yaitu menyajikan metode yang tepat dalam baca tulis Al-Qur'an salah satu syaratnya adalah peran dari seorang guru. Guru yang berkualitas penuh daya juang yang efektif dan inovatif sangat perlu diharapkan karena dalam perkembangan siswa hal tersebut sangat penting seperti yang dikatakan oleh Ravik Karsidi bahwa guru sangat diharapkan mampu membimbing siswa sesuai peranannya yaitu peran guru terhadap peserta didik merupakan vital dari sekian peran yang harus dijalani, yaitu memberikan keteladanan, pengalaman serta ilmu pengetahuan kepada peserta didik. ${ }^{4}$

Hal ini juga ditegaskan oleh Sumadi Suryabrata bahwa peranan pendidik sangat besar dalam penentuan pandangan hidup siswa, karena itulah kenalilah mereka dan berikanlah mereka bimbingan. ${ }^{5}$

Guru yang memiliki karakteristik sebagai pembimbing walaupun masih dalam tahap awal mampu menunjukan interaksi yang dinamis antara guru dan peserta didik dalam praktek belajar mengajar yang bernuansa bimbingan, mereka juga memiliki kemampuan untuk membimbing peserta didik yang bermasalah. Misalnya masalah dalam belajar, penyesuaian diri, masalah akibat keluarga yang tidak sehat, pengaruh TV, internet dan lainlain.

Hasil observasi di TPQ Miftahul Ulum adalah rendahnya semangat untuk baca tulis Al-Qur'an ini banyak ditemukan. Misalnya kurangnya keseriusan dalam membaca dan menulis Al-Qur'an. Masalah tersebut dapat menghambat proses baca tulis Al-Qur'an dikarenakan kurangnya motivasi.

Dari latar belakang di atas maka peneliti tertarik untuk meneliti bagaimana peran dan upaya guru untuk meningkatkan kualitas dalam baca tulis Al-Qur'an di TPQ Miftahul Ulum Nglele Sumobito Jombang

Mengingat luasnya masalah penelitian tentang peran guru dalam upaya meningkatkan kualitas baca tulis Al-Qur`an di TPQ maka perlu sekiranya peneliti memberikan ruang lingkup dalam masalah ini. Adapun ruang lingkup ini adalah:

Dalam penelitian ini mengambil batasan pengertian tertentu untuk membatasi bahasan dan agar penelitian bisa dilaksanakan lebih detail sebagai berikut:

\footnotetext{
${ }^{4}$ Ravik Rasidi, Sosiologi Pendidikan (Solo: Lembaga Pendidikan, 2007), 3.

${ }^{5}$ Sumadi Suryabrata, Psikologi Pendidikan (Jakarta: Raja Grafindo, 2006), 35.
} 
182 ][ Peran Guru dalam Upaya Meningkatkan Kualitas Baca Tulis Al-Qur'an

Peran utama seorang guru adalah menyampaikan ilmu pengetahuan sebagai warisan kebudayaan masa lalu yang yang dianggap berguna sehingga harus dilestarikan. Guru mempunyai peran yang sangat penting dalam proses pembelajaran, bagaimanapun hebatnya teknologi

\section{KAJIAN TEORI}

\section{Kualitas baca tulis Al-Qur'an}

Penelitian ini bertempat di TPQ Miftahul Ulum Nglele Sumobito Jombang. Subjek dari penelitian ini adalah seluruh guru di TPQ Miftahul Ulum Nglele Sumobito Jombang. Untuk mendapat hasil dari penelitian judul ini yang relevan dan akurat, peneliti membutuhkan waktu untuk meneliti selama 4 (empat) bulan dari bulan Januari sampai akhir bulan April 2017.

Berangkat dari latar belakang yang telah diuraikan diatas, terdapat beberapa pokok permasalahan yang menjadi fokus penulis. Pokok persoalan tersebut dapat dirumuskan dalam rumusan masalah sebagai berikut:

Pertama, Bagaimana peran guru di TPQ untuk meningkatkan kualitas baca tulis Al-Qur`an di TPQ Miftahul Ulum Nglele Sumobito Jombang?

Kedua, Bagaimana upaya meningkatkan kualitas baca tulis Al-Qur`an di TPQ Miftahul Ulum Nglele Sumobito Jombang?

Ketiga, Apa faktor penunjang dan penghambat peran guru dalam upaya meningkatkan baca tulis Al-Qur`an di TPQ Miftahul Ulum Nglele Sumobito Jombang?

Sebagai bahan acuan dan perbandingan skripsi ini, peneliti menemukan dua penelitian terdahulu, diantaranya:

Peneliti Mulyati, berjudu "peranan taman pendidikan al-qur'an (TPA) At-Thohiriyah dalam pembinaan akhlak anak". Jenis penelitian yang digunakan adalah penelitian kualitatif. Hasil penelitian ini menunjukkan bahwa peranan TPA dalam pembinaan akhlak anak dilakukan melalui bimbingan keagamaan yang terkait dengan penyampaian materi pelajaran, penggunaan metode, dan pelaksanaan kegiatan. ${ }^{6}$

Peneliti Inka Crisnawati, berjudul "peran dan upaya guru meningkatkan motivasi tahfiz AL-Qur`an kelas V Di SDIT Luqman AlHakim Internasional Banguntapang Bantul Yogyakarta". Jenis penelitian yang digunakan adalah penelitian kualitatif. Hasil penelitian ini

\footnotetext{
${ }^{6}$ Mulyati, PerananTamanPendidikanAl-Qur'an (TPA) AT-THOHIRIYAH dalam Pembinaan Akhlak Anak (Skripsi: UNNES Semarang, 2005). 5.
} 
menunjukkan peran guru sebagai motivator dalam meningkatkan motivasi tahfiz AL-Qur`an pada siswa kelas V SDIT Luqman Al-Hakim Internasional ada dua yaitu : memberikan tugas kepada siswa dan memberikan motivasi kepada siswa agar menghafal Al-Qur`an dengan sungguh-sungguh. ${ }^{7}$

Persamaan posisi peneliti terdahulu dengan yang ingin diteliti yaitu sama-sama menggunakan penelitian kualitatif. Sedangkan perbedaan posisi peneliti terdahulu dengan yang ingin diteliti saat ini adalah peneliti terdahulu pada poin pertama menjelaskan peranan taman pendidikan al-qur'an (TPA) At-Thohiriyah dalam pembinaan akhlak anak. Pada poin kedua peneliti terdahulu menjelaskan tentang peran dan upaya guru meningkatkan motivasi tahfiz Al-Qur`an kelas V Di SDIT Luqman Al-Hakim Internasional Banguntapan Bantul Yogyakarta. Sedangkan penelitian ini lebih menitik beratkan Peran Guru Dalam Upaya Meningkatkan Kualitas Baca Tulis AlQur`an di TPQ Miftahul Ulum Nglele Sumobito Jombang

\section{PEMBAHASAN}

\section{Kajian Tentang Guru}

Pendidikan adalah usaha sadar dan terencana untuk mewujudkan suasana belajar dan proses pembelajaran agar peserta didik secara aktif mengembangkan potensi dirinya untuk memiliki kekuatan spiritual keagamaan, pengendalian diri, kepribadian, kecerdasan, akhlak mulia, serta keterampilan yang diperlukan dirinya, masyarakat, bangsa dan negara.

Guru adalah pendidik, yang menjadi tokoh, panutan, dan identifikasi bagi para peserta didik, dan lingkungannya. Oleh karena itu, guru harus memiliki standar kualitas pribadi tertentu yang mencakup tanggung jawab, wibawa, mandiri, dan disiplin. ${ }^{8}$

Pendidik adalah tenaga kependidikan yang berkualifikasi sebagai guru, dosen, konselor, pamong belajar, widyaiswara, tutor, instruktur, fasilitator, dan sebutan lain yang sesuai dengan kekhususannya, serta berpartisipasi dalam menyelenggarakan pendidikan.Satuan pendidikan adalah kelompok layanan pendidikan yang menyelenggarakan pendidikan pada jalur formal, nonformal, dan informal pada setiap jenjang dan jenis

\footnotetext{
${ }^{7}$ Inka Crisnawati, Peran danUupaya Guru Meningkatkan Motivasi Tahfiz Al-Qur`an Kelas $V$ di SDIT Luqman Al-Hakim Internasional Banguntapan Bantul Yogyakarta (Skripsi: UINSK Yogyakarta, 2015), 6.

${ }^{8}$ Mulyasa, Menjadi Guru Profesional (Bandung: Remaja Rosdakarya, 2005), 37.
} 
184 ][ Peran Guru dalam Upaya Meningkatkan Kualitas Baca Tulis Al-Qur'an

pendidikan. Dan pengertian formal, nonformal, dan informal sebagai berikut:

Pendidikan formal adalah jalur pendidikan yang terstruktur dan berjenjang yang terdiri atas pendidikan dasar, pendidikan menengah, dan pendidikan tinggi.

Pendidikan nonformal adalah jalur pendidikan di luar pendidikan formal yang dapat dilaksanakan secara terstruktur dan berjenjang.

Pendidikan informal adalah jalur pendidikan keluarga dan lingkungan.

Berkaitan dengan tanggung jawab: guru harus mengetahui, serta memahami nilai norma moral, dan sosial, serta berusaha berprilaku dan berbuat sesuai dengan nilai dan norma tersebu, guru juga harus bertanggungjawab terhadap segala tindakannya dalam pembelajaran di sekolah, dan dalam kehidupan bermasyarakat.

Berkaitan dengan wibawa: guru harus memiliki kelebihan dalam merealisasikan nilai spiritual, emosional, moral, sosial, dan telektual dalam pribadinya, serta memiliki kelebihan dalam pemahaman ilmu pengetahuan, teknologi, dan seni sesuai dengan bidang yang dikembangkan.

Guru juga harus mampu mengambil keputusan secara mandiri, terutama dalam berbagai hal yang berkaitan dengan pembelajaran dan pembentukan kompetensi, serta bertindak sesuai dengan kondisi peserta didik, dan lingkungan. Guru harus mampu bertindak dan mengambil keputusan secara cepat, tepat waktu, dan tepat sasaran, terutama berkaitan dengan masalah pembelajaran dan peserta didik, tidak menunggu perintah atasan atau kepala sekolah.

Sedangkan disiplin: dimaksudkan bahwa guru harus mematuhi berbagai peraturan dan tata tertib secara konsisten, atas kesadaran professional, karena mereka bertugas untuk mendisiplinkan para peserta didik di sekolah, terutama dalam pembelajaran. Oleh karena itu, dalam menanamkan disiplin guru harus memulai dari dirinya sendiri, dalam berbagai tindakan dan perilakunya. ${ }^{9}$

${ }^{9}$ Ibid., 38

Jurnal al-Murabli, Volume 4 Namar 2, Juni 2019 


\section{Peranan Guru}

Sehubungan dengan fungsinya sebagai pengajar, pendidik dan pembimbing, maka diperlukan adanya berbagai peranan pada diri guru. Dari berbagai kegiatan interaksi belajar mengajar, dapat dipandang sebagai sentral bagi peranannya, sebab baik disadari atau tidak bahwa sebagian dari waktu dan perhatian guru banyak dicurahkan untuk menggarap dan berinteraksi dengan siswanya. ${ }^{10}$

Peranan guru dalam kegiatan belajar mengajar, secara singkat dapat disebutkan sebagai berikut:

Informator

Sebagai pelaksana cara mengajar informative, laboratorium studi lapangan dan sumber informasi kegiatan akademik maupun umum.

Organisator

Guru sebagi organisor, pengelola kegiatan akademik, silabus, workshop, jadwal pelajaran, dan lain-lain.

Motivator

Peran guru sebagai motivator ini penting artinya dalam rangka meningkatakan kegairahan dan pengembangan kegiatan siswa. Guru harus dapat merangsang dan memberikan dorongan untuk mendinamiskan potensi siswa.

Demonstrator

Peranan guru sebagai demonstrator artinya hendaknya senantiasa menguasai bahan atau materi pelajaran yang akan diajarkan serta senantiasa mengembangkannya dalam arti meningkatkan kemampuannya dalam hal ilmu yang dimilikinya karena hal ini sangat menentukan hasil belajar yang dicapai siswa. ${ }^{11}$

Guru sebagi pengelola kelas

Dalam peranannya sebagai pengelola kelas, guru hendaknya mampu mengelola kelas sebagai lingkungan sekolah yang perlu diorganisasi. Kualitas belajar siswa didalam kelas bergantung pada banyak faktor antara lain: guru, hubungan pribadi antar siswa didalam kelas, serta kondisi umum dan suasana didalam kelas. Tujuan umum pengelola kelas adalah menyediakan dan menggunakan fasilitas kelas untuk bermacammacam kegiatan belajar dan mengajar agar mencapai hasil yang baik.

${ }^{10}$ Sardiman, Interaksi dan Motivasi Belajar Mengajar (Jakarta: Raja Grafindo Persada, 2001 ), 142 .

${ }^{11}$ Moh. Uzer Usman, Menjadi Guru Profesional (Bandung: Remaja Rosdakarya,1995), 9. 
186 ][ Peran Guru dalam Upaya Meningkatkan Kualitas Baca Tulis Al-Qur'an

Sedangkan tujuan khususnya alat-alat belajar, menyediakan kondisikondisi yang memungkinkan siswa belajar dan belajar, serta membantu siswa untuk memperoleh hasil yang diharapkan. ${ }^{12}$

Guru sebagi mediator

Sebagai mediator guru hendaknya memiliki pengetahuan dan pemahaman yang cukup tentang media pendidikan karena media pendidikan merupakan alat komunikasi untuk lebih mengefektifkan proses belajar mengajar.

\section{Kajian tentang Kualitas Baca Tulis Al-Qur`an}

Pengerian Membaca

Membaca

Baca $b a-c a$, membacamem-ba-ca, membaca juga dapat diartikan dengan:

melihat serta memahami isi dari apa yang tertulis (dengan melisankan atau hanya dalam hati)

mengeja atau melafalkan apa yangtertulis.

Mengucapkan

mengetahui, meramalkan. Suratan tangan (garis-garis pada telapak tangan)

memperhitungkan, memahami

bahasa (jenis mata pelajaran) membaca sambil mempelajari maknakata dari bahan bacaan

batin membaca dalam hati

bibir mencoba mengerti pembicaraan lewat gerak bibir (terutama bagi tunarungu)

cepat (jenis) membaca dalam hati dengan tujuan memperoleh informasi yang sebanyak-banyaknya dan dalam waktu yang sesingkat-singkatnya.

dalam hati membaca tanpa bersuara (tidak diucapkan)

teknis (sebagai mata pelajaran) membaca nyaring dengan memperhatikan nada, dinamika, dan tempo.

Dalam KBBI WJS. Poerwadarminto, membaca memiliki arti melihat tulisan dan mengerti atau dapat melisankan apa yang tertulis itu. ${ }^{13}$ Membaca merupakan salah satu aktivitas belajar. Hakikat membaca

\footnotetext{
${ }^{12}$ Ibid., 10.

${ }^{13}$ WJS. Poerwadarminto, Kamus Umum Bahasa Indonesia (Jakarta: Balai Pustaka, 1987), 71. 
adalah suatu proses yang kompleks dan rumit karena dipengaruhi oleh faktor internal dan eksternal yang bertujuan untuk memahami arti atau makna yang ada dalam tulisan tersebut. Wahyu pertama yang disampaikan kepada Nabi Muhammad SAW adalah perintah membaca karena dengan membaca Allah mengajarkan tentang suatu pengetahuan yang tidak diketahuinya. Dengan membaca manusia akan mendapatkan wawasan tentang suatu ilmu pengetahuan yang akan berguna bagi dirinya kelak.

Ditinjau dari segi kebahasaan, ada beberapa pendapat yang mengartikan Al Qur'an antara lain :

Menurut pendapat para qurro, kata "Qur'an" berasal dari kata "qorooin" yang berarti “qorina”. Maksudnya bahwa ayat-ayat Al Qur'an yang satu dengan yang lainnya saling membenarkan.

Dan menurut pendapat yang termasyhur kata "Qur'an" berasal dari kata "qoroa" yang berarti "bacaan". ${ }^{14}$ Pengertian ini diambil berdasarkan ayat Al-Qur'an Surat Al-Qiyamah ayat : 17-18 :

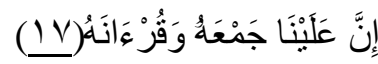

Artinya: "Sesungguhnya atas tanggungan Kamilah mengumpulkannya (didadamu) dan (membuatmu pandai) membacanya".

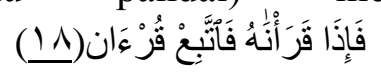

Artinya: "Apabila Kami telah selesai membacakannya maka ikutilah bacaannya itu".

Jadi membaca adalah suatu usaha mengolah bahan bacaan yang berupa simbol atau tulisan yang berisi pesan peneliti. ${ }^{15}$ Dalam ajaran islam membaca yang terpenting adalah membaca sesuatu yang bermanfaat baik didunia maupun di akhirat,dan membaca yang sangat dianjurkan serta diperintahkan oleh Allah adalah membaca Al-Qur'an.

Sebagai manusia yang beragama, selalu dituntut untuk senantiasa membaca dalam arti membaca ayat-ayat atau tanda-tanda kebesaran Allah dimuka bumi ini. Bahkan ayat-ayat Al-Qur'an sendiriyang pertama kali diturunkan adalah perintah kepada umat manusia untuk

\footnotetext{
${ }^{14}$ Moh. Chadziq Charisma, Tiga Aspek Kemukjizatan Al-Quran (Surabaya: Bina Ilmu, 1991), 1

${ }^{15}$ Oemar Hamalik, Teknik Pengukuran dan Evaluasi Pendidikan (Bandung: Mandar Maju, 1989), 4.
} 
membaca dan menulis. Adapun yang dimaksud dalam penelitian ini adalah kemampuan maembaca yang baik dan benar itu tidak boleh meninggalkan kaidah-kaidah ilmu tajwid.

Tujuan Membaca Al-Qur`an

Tujuan utama dalam membaca adalah mencari serta memperoleh informasi, menangkap isidan memahami bacaan. ${ }^{16}$ Membaca juga merupakan kunci ilmu pengetahuan bagi seseorang, dengan membaca orang akan memiliki pengetahuan yang luas, pemikiran yang lebih kritis serta dapat mengetahui kebenaran, fakta,sehingga dapat membedakan antara yang benar dan yang salah.

Al-Qur'an dijadikan sebagai pedoman bagi setiap umat muslim, setiap muslim dianjurkan untuk membacanya serta memahami isi dari kandungan ayat tersebut. Maka dari itu perlu bagi kita untuk mempelajari Al-Qur'an, baik belajar membaca, menulis maupun mempelajari isi dari kandungan Al-Qur'an tersebut. Bagi orang yang beriman, kecintaannya kepada Al-Qur'an akan bertambah. Sebagai bukti cintanya, dia akan semakin bersemangat membacanya setiap waktu, mempelajari isi kandungan dan memahaminya. Selanjutnya, akan mengamalkan Al-Qur'an dalam kehidupannya sehari-hari, baik dalam hubungannya dengan Allah SWT maupun dengan lingkungan sekitarnya. Allah SWT berfirman dalam Qs.Al-Isra' ayat: 82:

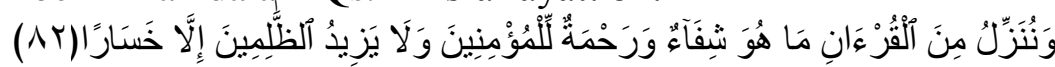

Artinya: "Dan kami turunkan dari Al-Qur"an (sesuatu) yang menjadi penawar dan rahmat bagi orang yang beriman, sedangkan bagi orang zalim (Al-Qur"an itu) hanya akan menambah kerugian".

Sebagaimana apa yang dibahas dalam peneltian ini tentang kemampuan membaca Al-Qur`an, maka tujuan dari membaca Al-Qur`an sendiri disini adalah untuk mendekaktkan diri kepada Allah, karena Al-Qur`an sendiri dikalangan islam merupakan bacaan nomor pertama dikala susah maupun senang. Dari keterangan ayat dan hadis diatas, dapat dimengerti bahwa AlQur'an merupakan sumber pokok ajaran Islam yang menjadi kebutuhan bagi setiap umat muslim, banyak ilmu dan pelajaran penting yang dapat diambil dari Al-Qur'an. Sehingga, seluruh umat Islam yang ada dimuka bumi ini dianjurkan untuk membaca serta mempelajarinya.

Jenis-Jenis Membaca

${ }^{16}$ Hernowo, Quantum Reading (Bandung: MLC, 2005), 33. 
Dalam keterampilan membaca terdapat beberapa jenis membaca yang bisa digunakan ketika pembelajaran, antara lain:

Membaca Keras

Kegiatan membaca ini ditekankan pada kemampuan membaca dengan ketepatan bunyi bahasa arab baik dari segi makhraj maupunsifat bunyi lain, irama yang tepat dan ekspresi yang mengambarkan perasaan penulis, lancar tidak tersendat-sendat dan selalu memperhatikan tanda baca.

Membaca dalam Hati

Membaca dalam hati bertujuan untuk memperoleh pengertian baik pokok-pokok maupun rincian-rinciannya. Oleh karena itu, ia merupakan bagian jenis membaca yang lain.

Membaca cepat

Tujuan utama membaca cepat adalah untuk menggalakkan siswa agar berani membaca lebih cepat dari pada kebiasaannya.

Membaca rekreatif

Tujuan utama membaca rekreatif adalah untuk membina minat dan kecintaan siswa untuk membaca.

\section{Membaca analitif}

Tujuan utama membaca analitif adalah untuk melatih siswa agar memiliki kemampuan mencari informasi dari bahan tertulis. Selain itu siswa dilatih agar berpikir logis, mencari hubungan antara kejadian dengan kejadian lain dan menarik kesimpulan walaupun ia tidak tertulis secara eksplisit dalam bacaan. ${ }^{17}$

Pengertian Menulis

Tulistu-lis, bertulisber-tu-lis, ada huruf (angka dan sebagainya) yang dibuat (digurat dan sebagainya) dengan pena (pensil, cat, dan sebagainya); yang ditulis dengan tangan (tidak dicetak).

Menulis dapat di artikan sebagi berikut:

membuat huruf (angka dan sebagainya) dengan pena (pensil, kapur, dan sebagainya).

melahirkan pikiran atau perasaan (seperti mengarang, membuat surat) dengan tulisan: mengarang cerita, membuat surat, berkirim surat. Menggambar, melukis.

${ }^{17}$ Ahmad Fuad Efendi, Metodologi Pengajaran Bahasa Arab (Malang: Misykat, 2009), 129131. 
190 ][ Peran Guru dalam Upaya Meningkatkan Kualitas Baca Tulis Al-Qur'an

membatik (kain).

Menurut Rudy S. Iskandar menulis adalah kegiatan menuangkan simbol huruf, sedangkan huruf adalah bentuk-bentuk yang merupakan lambang bunyi seperti "a" dari alat bunyi yang berada dalam rongga mulut dengan rongga dibuka lebar, sedangkan huruf'b" adalah lambang bunyi jika bibir atas dan bawah dietupkan. ${ }^{18} \mathrm{Jadi}$ menulis adalah menuangkan simbol lambang dan bunyi. Dalam aktivitas menulis terdapat tiga komponen penting, yaitu:

Penguasaan bahasa tulis, meliputi kosakata, struktur kalimat paragraf, ejaan, pragmatik dan sebagainya.

Penguasaan isi karangan sesuai dengan topik yang akan ditulis.

Penguasaan tentang jenis-jenis tulisan.

Pada dasarnya, menulis merupakan suatu kegiatan yang produktif dan ekspresif. Dalam kegiatan menulis, sesorang harus trampil memanfaatkan grofologi, struktur bahasa, dan kosakata. Tujuan menulis adalah mencatat, merekam, meyakinkan dan mempengaruhi pembaca. Hal tersebut hanya bisa dicapai hanya dengan baik oleh pelajar yang mampu menyusun dan merangkai jalan pikiran, mengemukakannya serta tulis dengan jelas, lancar dan komunikatif. ${ }^{19}$

Tahap-Tahap Latihan Menulis

Latihan Kebahasaan

Latihan kebahasaan mempunyai banyak ragam, anatara lain latihan rekombinasi dan transformasi. Rekombinasi adalah latihan menggabungkan kalimat-kalimat yang mulanya berdiri sendiri menjadi suatu kalimat panjang. Sedangkan transformasi adalah latihan mengubah bentuk kalimat, dari kalimat positif menjadikalimat negatife dan lain sebagainya.

Mencontoh

Pertama, siswa belajar dan melatih diri menulis dengan tepat sesuai dengan contoh.

Kedua, siswa belajar mengeja dengan benar.

Ketiga, siswa berlatih menggunakan bahasa arab yang benar.

Reproduksi

\footnotetext{
${ }^{18}$ Rudy S, Iskandar, Pengenalan Tipografi (tp: Buletin Pusat Perbukuan, 2002), 27.

${ }^{19}$ Efendi Anwar, Bahasa Dan Sastra Sebagai Prespektif (Yogyakarta: Tiara Wacana 2005), 327.
} 
Reproduksi adalah menulis berdasarkan apa yang telah dipelajari secara lisan. Dalam tahap ini siswa suadah mulai dilatih menulis tanpa ada model. Model lisan tetap ada dan harus model yang benar-benar baik. Imlak

Pada tahap ini, imlak melatihkan ejaan dan penggunaan gendang telinga. Ada dua macam imlak yang biasanya digunakan, antara lain: imlak yang sudah di persiapakan sebelumnya.

Mengarang Terpimpin

Pada tahap ini, murid mulai dikenalkan dengan penulisan alenia, walaupun sifatnya masih terpimpin.

Mengarang Bebas

Tahap ini merupakan tahap yang melatih siswa mengutarakan isi hatinya dengan memilih kata-kata dan pola kalimat secar bebas. Namun, guru hendaknya tetap memberikan bimbingan dan pengarahan kepada siswa terkait dengan apa yang akan mereka tulis. ${ }^{20}$

Faktor-Faktor yang Mempengaruhi Baca/Membaca Al-Qur`an

Faktor-faktor penyebab yang mempengaruhi kemampuan mambaca AlQur`an sebagi mana yang dikemukakan oleh Jalaluddin adalah sebagai berikut:

Orientasi berpikir

Pengaruh modernisasi banyak mempengaruhi arah pemikiran orang. Kemajuan teknologi dengan segala hasil yang disumbangkannya bagi kemudahan hidup manusia, banyak mengalihkan perhatian orang untuk hidup lebih erat dengan alam kebendaan. Hal ini mendorong mereka untuk menuntut ilmu yang diperkirakan pengetahuan praktis dan menunjang prestise(wibawa) kehidupan.

Pengetahuan tentang Al-Qur`an dan cara membacanya kalah bersaing di alam pemikiran kebanyakan kaum muslimin, hingga hampir diabaikan. Padahal bidang tersebut merupakan disiplin imu tersendiri hingga untuk menguasainya diperlukan sistem dan metode tersendiri pula disamping ketentuan dan waktu yang cukup lama.

Kesempatan dan Tenaga

Arah berfikir yang materialistis telah mendudukkan status wajib belajar Al-Qur`an ke posisi yang lebih kecil. Pengaruhnya ini telah menimbulkan kondisi alasan-alasan. Akibatnya terjadi kelangkaan

${ }^{20}$ Ibid.,. 171. 
penyediaan kesempatan dan kelangkaan tenaga. Waktu yang disediakan untuk belajar Al-Qur`an sangat sedikit jika dibandingkan dengan waktu mereka yang digunakan untuk menuntut ilmu pengetahuan lain. Akhirnya tenaga pengajar tersedia tidak sempat berkembang seimbang dengan kebutuhan.

Metode

Perkembangan teknologi telah merubah kecenderungan masyarakat untuk menuntut pengetahuan secara lebih mudah dan lebih cepat. Untuk menampung minat ini dalam berbagai disiplin ilmu, pra ahli telah memanfaatkan jasa teknologi dalam media pendidikan baik media visual, audio-visual, computer dengan cara yang semakin tepat guna.

Khusus dalam pendidikan Al-Qur`an cara ini masih langka dan mahal. Metode lama dalam beberapa seginya mungkin sudah kurang sesuai dengan keinginan dan kecenderungan tepat guna ini. Akibatnya metode yang demikian berangsur kurang diminati.

Aksara

Kitab suci Al-Qur`an ditulis dengan aksara dan bahasa arab faktor ini menyulitkan bagi mereka yang berpendidikan non pesantren/madrasah karena pengetahuan itu tidak dikembangkan secara khusus disekolah umum. Akibatnya pelajar yang berpendidikan umum sebagin besar buta aksara kitab sucinya. Kebutuhan aksaran ini membuat jejak makin lama makin jauh antara mereka dengan kitab sucinya.

Macam-Macam Metode Membaca Al-Qur`an

Metode adalah alat yang harus ada apabila kita ingin memudahkan sesuatu pembelajaran dalam pengajaran untuk mencapai tujuan pembelajaran. Sedangkan membaca adalah suatu usaha mengolah bahan bacaan yang berupa simbol atau tulisan yang berisi pesan peneliti. Dalam proses pembelajaran, metode mempunyai peranan sangat penting dalam upaya pencapaian tujuan pembelajaran. Adapun macam-macam metode membaca Al-Qur'an diantaranya adalah sebagai berikut:

Metode Tradisional

Metode ini paling lama digunakan di kalangan umat islam Indonesia dan metode pengajaran memerlukan waktu yang cukup lama. Adapun pengajaran metode ini adalah anak didik terlebih dahulu harus mengenal 
dan menghafal huruf hijaiyah yang berjumlah 28 (selain Hamzah dan Alif). ${ }^{21}$

Metode Iqra`

Metode Iqro' adalah suatu metode membaca Al-Qur'an yang menekankan langsung pada latihan membaca. Adapun buku panduan Iqro' terdiri dari 6 jilid di mulai dari tingkat yang sederhana, tahap demi tahap sampai pada tingkatan yang sempurna. Metode Iqro' ini dalam prakteknya tidak membutuhkan alat yang bermacam-macam, karena ditekankan pada bacaannya (membaca huruf Al-Qur'an dengan fasih), bacaan langsung tanpa dieja. Artinya diperkenalkan nama-nama huruf hijaiyah dengan cara belajar siswa aktif (CBSA) dan lebih bersifat individual

Metode pengajaran ini pertama kali disusun oleh H.As`ad human, di Yogyakarta. Metode Iqra' adalah suatu metode membaca Al-Qur`an yang menekankan langsung pada latihan membaca. ${ }^{22}$

Adapun kelemahan dan kelebihan metode Iqro' adalah: 1) Kelebihan Pertama, Menggunakan metode cara belajar siswa aktif, jadi bukan guru yang aktif melainkan santri yang dituntut aktif.

Kedua, Dalam penerapannya menggunakan klasikal (membaca secara bersama) privat, maupun cara eksistensi (santri yang lebih tinggi jilidnya dapat menyimak bacaan temannya yang berjilid rendah).

Ketiga, Komunikatif artinya jika santri mampu membaca dengan baik dan benar guru dapat memberikan sanjungan, perhatian dan penghargaan.

Keempat, Bila ada santri yang sama tingkat pelajarannya, boleh dengan sistem tadarus, secara bergilir membaca sekitar dua baris sedang lainnya menyimak.

keLima, Bukunya mudah di dapat di toko-toko.

Kekurangan

Pertama, Bacaan-bacaan tajwid tak dikenalkan sejak dini.

Kedua, Tak ada media belajar 3 . Tak dianjurkan menggunakan irama murottal.

\footnotetext{
${ }^{21}$ Siti Zahroh, Metode Pembelajaran AL-Qur`an Dalam Meningkatkan Perkembangan Jiwa Keagamaan Anak Studi Kasus Di TPQ Nur Chasanah Gondang Legi Malag (Skripsi, UIN Malang, 2006), 16.

${ }^{22}$ Ibid., 17.
} 
194 ][ Peran Guru dalam Upaya Meningkatkan Kualitas Baca Tulis Al-Qur'an

Metode Tilawati

Metode tilawati disusun pada tahun 2007 oleh tim yang terdiri dari Drs.H.Hasan Sadzili,dkk. Salah satu keistimewaan metode tilawati adalah adanya standarisasi guru, standarisasi strategi, pengajaran, standarisasi munaqosah. Adpun bagi guru diadakan pembinaan dan tashih binnadhor(melihat) pada tutorial satu minggu sekali. ${ }^{23}$

Faktor-faktor yang mempengaruhi kemampuan dalam menulis

Seseorang yang belajar membaca Al-Qur’an memiliki kemampuan berbeda-beda antara satu anak didik dengan anak didik lainnya. Kemampuan membaca Al-Qur`an setiap anak didik tersebut dipengaruhi oleh berbagai faktor baik yang bersifat internal maupun eksternal. Adapun faktor-faktor tersebut yaitu:

Faktor-faktor non sosial ( internal)

Faktor non sosial ( internal) adalah faktor-faktor yang dapat mempengaruhi kemampuan dan keberhasilan belajar yang bukan berasal dari pengaruh manusia.

Faktor-Faktor sosial (eksternal)

Faktor manusia atau semua manusia, baik manusia itu ada atau hadir secara langsung maupun tidak langsung maupun tidak langsung kehadiran orang lain pada waktu sedang belajar sering kali mengganggu aktivitas belajar. $^{24}$

\section{ANALISIS DATA HASIL PENELITIAN}

Peran guru dalam meningkatkan kualitas baca tulis Al-Qur`an di TPQ Miftahul Ulum Nglele Sumobito Jombang

Peran guru sangatlah penting dalam upaya meningkatkan kualitas baca tulis A-Qur’an terhadap santri, karena peran guru memiliki faktor keterlibatan yang sangat besar terhadap kemajuan para santrinya.

Dalam baca tulis Al-Qur`an anak didik bukanlah suatu hal yang begitu saja berjalan tanpa proses. Tetapi memerlukan suatu upaya-upaya guru yang konkrit. Ada beberapa upaya yang harus dilakukan guru dalam upaya

\footnotetext{
${ }^{23}$ Nurul Faizah, Pengaruh Penggunaan Metode An-Nadhiyah ,Adz-DizkrDan Tilawati Terhadap Kemampuan Pra Membaca AL-Qur`an Anak Tunagrahita DiTPQ Al-Khoirul Jampirogo Sooko Mojokerto (Skripsi UNIPDU Jombang, 2013), 22.

${ }^{24}$ Mas`udah, Upaya Meningkatkan Kemampuan Baca Tulis AL-Qu an Melalui Metode Index Card Match Di RA Muslimat NU Angin-Angin Buko Wedung Demak (Skripsi Fakultas Tarbiyah Institut Agama Islam Negri Wali Songo, 2011), 13-14.
} 
meningkatkan kualitas baca tulis Al-Qur`an anak didik yaitu:

Menambah jam mengaji setelah pulang mengaji dari TPQ Miftahul Ulum dan Menciptakan kondisi yang baik pada waktu proses belajar mengajar, peran guru dalam upaya meningkatkan kualitas baca tulis AlQur`an harus memiliki kemampuan dan profesionalisme dalam baca tulis AlQur`an, karena kalau tidak memiliki kemampuan yang mumpuni maka akibatnya ke santri akan buruk, Mengingat mempelajari Al-Qur`an tidak boleh sembarangan, ada aturan-aturan tajwidnya, makharijul hurufnya, dan sebagainya. Dan kebanyakan santri di TPQ Miftahul Ulum Nglele Sumobito Jombang sudah banyak yang bisa membaca tuis Al-Qur'an dengan baik dan benar. upaya menciptakan kondisi yang baik ini juga bisa dalam bentuk memberikan sebuah metode yang menarik bagi santri dalam pembelajaran baca tulis Al-Qur`an.

Upaya peningkatan kualitas baca tulis Al-Qur`an di TPQ Miftahul Ulum Nglele Sumobito Jombang

Berdasarkan pada analisis data yang telah diperoleh peneliti, dari metode penelitian yang dilakukan untuk meningkatkan kualitas baca tulis AlQur`an memerlukan metode sebagai salah satu faktor yang mendukung lancarnya proses upaya peningkatan kualitas baca tulis Al-Qur`an dalam rangka mencapai tujuan. Tujuan tersebut adalah agar santri lebih aktif, kreatif dan inovatif. Upaya peningkatan kualitas baca tulis Al-Qur`an juga memerlukan metode pendidikan dan pengajaran yang tepat agar santri bisa memahami dan mempelajarinya. Akan tetapi tidak semua metode tersebut dapat dipakai dalam penyampaian suatu bahan. Akan tetapi tidak semua metode tersebut dapat dipakai dalam penyampaian suatu bahan dan metode tersebut yaitu :

Metode memberi contoh (tauladan)

Metode menghafal

Metode membiasakan

Metode perintah

Metode tugas

Metode Tanya jawab

Dengan metode-metode tersebut para ustad/ustadzah hasilnya akan sangat baik bagi santri-santri untuk membentuk kepribadian yang baik dan mengamalkan apa yang di anjurkan oleh agama islam di TPQ Miftahul Ulum Nglele Sumobito Jombang 
Faktor penunjang dan penghambat di TPQ Miftahul Ulum Nglele Sumobito Jombang

Faktor penunjang di TPQ Miftahul Ulum Nglele Sumobito Jombang sudah cukup baik, hal tersebut dapat dilihat dari sarana dan prasarana yang memadai dan motivasi belajar yang tinggi pada diri santri dan mampu melahirkan stimulus yang baik dan menumbuhkan minat belajar. Sedangkan Faktor penghambat kegiatan baca tulis Al-Qur`an pada santri TPQ Miftahul Ulum Nglele Sumobito Jombang sangat kurang, karena keterbatasan waktu dalam kegiatan pengabdian merupakan suatu kendala yang dapat menghambat jalannya kegiatan pembelajaran. Dan perbedaan intelegensi dan latar belakang setiap santri mempunyai kemampuan yang berbeda-beda, ada yang memiliki intelegensi yang tinggi dan ada pula yang intelegensinya rendah. Hal ini menyebabkan tingkat penerimaan dan penguasaan materi yang di berikan oleh tutor bervariasi, ada yang cepat menguasai, sedang da nada pula yang lambat.

Dari hasil penelitian diatas dapat diketahui bahwa Hasil dari peran guru dalam upaya peningkatan baca tulis Al-Qur`an sangat memuaskan terbukti dengan adanya santri bisa membaca Al- Qur an dengan baik dan benar.

Analisis data yang dilakukan pada penelitian tindakan kelas yaitu dilakukan sejak awal penelitian di lapangan. Aktivitas dalam analisis data yang digunakan dalam penelitian ini yaitu meliputi tiga langkah yaitu:

Data Reduction (Reduksi Data)

Mereduksi data berarti merangkum, memilih hal-hal yang pokok, memfokuskan pada hal-hal yang penting, dicari tema dan polanya. ${ }^{25}$ Jadi data yang diperoleh dari lapangan yang jumlahnya cukup banyak perlu dicatat secara teliti dan rinci. Sehingga dapat memberikan gambaran yang lebih jelas dan mempermudah peneliti untuk melakukan pengumpulan data selanjutnya.

Data Display (Penyajian Data)

Dalam penelitian kualitatif, penyajian data bisa dilakukan dalam bentuk uraian singkat, bagan, hubungan antara kategori, flowchart dan sejenisnya. Dengan mendisplaykan data, maka akan memudahkan untuk memahami apa yang terjadi, merencanakan kerja selanjutnya berdasarkan apa yang telah dipahami tersebut.

\footnotetext{
${ }^{25}$ Sugiyono, Metode Penelitian Kuantitatif, Kualitatif, dan R\&D (Bandung: Alfabeta, 2015), 247.
} 


\section{Data Conclusing Drawing/verification}

Pada tahap ini, peneliti melakukan penarikan kesimpulan yang ditarik dan dirumuskan dari kondisi catatan lapangan, pengkodean, penyimpanan dan metode-metode perbaikan yang digunakan, dan pengalaman penelitian.

\section{KESIMPULAN}

Berdasarkan pada penelitian yang telah di lakukan dengan judul "Peran Guru dalam Upaya Meningkatkan Kualitas Baca Tulis Al-Qur`an di TPQ Miftahul Ulum Nglele Sumobito Jombang". Maka peneliti dapat memberikan suatu kesimpulan sebagai berikut:

Peran guru dalam meningkatkan kualitas baca tulis Al-Qur`an di TPQ Miftahul Ulum Nglele Sumobito Jombang. Dalam baca tulis Al-Qur`an anak didik bukanlah suatu hal yang begitu saja berjalan tanpa proses. Tetapi memerlukan suatu upaya-upaya guru yang konkrit. Ada beberapa upaya yang harus dilakukan guru dalam upaya meningkatkan kualitas baca tulis AlQur`an anak didik yaitu :

Menambah jam mengaji setelah pulang mengaji dari TPQ Miftahul Ulum

Menciptakan kondisi yang baik pada waktu proses belajar mengajar

Upaya peningkatan kualitas baca tulis Al-Qur`an di TPQ Miftahul Ulum Nglele Sumobito Jombang. juga memerlukan metode pendidikan dan pengajaran yang tepat agar santri bisa memahami dan mempelajari metode tersebut. Tetapi tidak semua metode tersebut dapat dipakai dalam penyampaian suatu bahan. Metode tersebut antara lain :

Metode memberikan cotoh (tauladan)

Metode membiasakan

Metode perintah

Metode pemberian tugas

Metode Tanya jawab

Faktor penunjang dan penghambat di TPQ Miftahul Ulum Nglele Sumobito Jombang. Faktor-faktor tersebut yaitu :

Faktor penunjang

Faktor pendukung kegiatan baca tulis Al-Qur’an pada santri Miftahul Ulum Nglele Sumobito Jombang ada dua yaitu :

Motivasi belajar

Sarana prasana yang memadai 
198 ][ Peran Guru dalam Upaya Meningkatkan Kualitas Baca Tulis Al-Qur'an

Faktor penghambat

Faktor penghambat kegiatan baca tulis Al-Qur`an pada santri Miftahul Ulum Nglele Sumobito Jombang ada dua yaitu :

Keterbatasan waktu dalam kegiatan pengabdian

Perbedaan intelegensi dan latar belakang

\section{DAFTAR PUSTAKA}

Akhofulloh, Am. Wawancara, Jombang, 12 maret 2017.

Aliyah, Nur. Wawancara, Jombang, 10 maret 2017.

Anwar, Efendi. 2005. Bahasa Dan Sastra Sebagai Prespektif. Yogyakarta: Tiara Wacana.

Arikunto, Suharsimi. 2010.Prosedur Penelitian Suatu Pendekatan Praktik. Jakarta: Rineka Cipta.

Chadziq Charisma, Moh. 1991.Tiga Aspek Kemukjizatan Al-Quran. Surabaya: Bina Ilmu.Darmadi, Hamid. 2013. Dimensi-Dimensi Metode Penelitian Pendidan dan Sosial Konsep Dasar dan Implementasi. Bandung: Alfabeta.

Efendi, Ahmad Fuad. 2009. Metodologi Pengajaran Bahasa Arab. Malang: Misykat.

Faizah, Nurul. 2013. Pengaruh Penggunaan Metode An-Nadhiyah, AdzDizkrDan Tilawati Terhadap Kemampuan Pra Membaca AL-Qur`an Anak Tunagrahita DiTPQ Al-Khoirul Jampirogo Sooko Mojokerto. Skripsi UNIPDU Jombang.

Habib, Nur. Wawancara, Jombang, 4 Mei 2017.

Hamalik, Oemar. 1989. Teknik Pengukuran dan Evaluasi Pendidikan. Bandung: Mandar Maju.

Hernowo. 2005.Quantum Reading. Bandung: MLC.

Indrakusuman, Amir Daien. 1973. Pengantar Ilmu Pendidikan, Surabaya: Usaha Nasional.

Inka Crisnawati, 2015. Peran danUupaya Guru Meningkatkan Motivasi Tahfiz Al-Qur`an Kelas $V$ di SDIT Luqman Al-Hakim. Skripsi:

UINSK Yogyakarta.

Mas`ah. Wawancara, Jombang, 3 Mei 2017.

Mas`udah. 2011.Upaya Meningkatkan Kemampuan Baca Tulis AL-Qu`an Melalui Metode Index Card Match Di RA Muslimat NU Angin-Angin Buko Wedung Demak.Skripsi Fakultas Tarbiyah. IAIN Wali Songo. 
Moleong, Lexy J. 2005. Metodologi Penellitian Kualitatif. Bandung: Remaja Rosdakarya.

Mulyasa. 2005. Menjadi Guru Profesional. Bandung: Remaj Rosdakarya.

Mulyati, 2005. PerananTamanPendidikanAl-Qur'an (TPA) ATTHOHIRIYAH dalam Pembinaan Akhlak Anak. Skripsi: UNNES Semarang.

Poerwadarminto, WJS. 1987. Kamus Umum Bahasa Indonesia. Jakarta: Balai Pustaka.

Qohar, Abd. Wawancara, Jombang, 10 maret 2017.

Rasidi, Ravik. 2007. Sosiologi Pendidikan. Solo: Lembaga Pendidikan.

Sabarudin, Boge. 2010. Peran Orangtua dan Guru dalam Meningkatkan Motivasi Belajar Membaca Al-Qur'an di SD Negeri Depok Sleman Yogyakarta, Fakultas Tarbiyah Universitas Islam Negeri Sunan Kalijaga.

Sardiman. 2001. Interaksi dan Motivasi Belajar Mengajar. Jakarta:Raja Grafindo Persada.

Sugiyono. 2015.Metode Penelitian Kuantitatif, Kualitatif, dan $R \& D$. Bandung: Alfabeta.

Suryabrata, Sumadi. 2006. Psikologi Pendidikan. Jakarta: Raja Grafindo.

Suryanto, Adi dkk. 2008. Evaluasi Pembelajaran di SD,Jakarta: Universitas Terbuka.

Syah, Muhibbin. 2005. Psikologi Pendidikan dengan Pendekatan Baru. Bandung: Rosdakarya.

Syaodih Sukmadinata, Nana. 2009. Meetode Penelitian Pendidikan. Bandung: Remaja Rosdakarya.

Uzer Usman, Moh. 1995. Menjadi Guru Profesional. Bandung: Remaja Rosdakarya.

Zahroh, Siti. 2006. Metode Pembelajaran AL-Qur`an Dalam Meningkatkan Perkembangan Jiwa Keagamaan Anak Studi Kasus Di TPQ Nur ChasanahGondang Legi Malang. Skripsi,UIN Malang. 
200 ][ Peran Guru dalam Upaya Meningkatkan Kualitas Baca Tulis Al-Qur'an

Nurnal al-Murabli, Volume 4 Namar 2, Jumi 2019 